\title{
Hithpael and Niphal in Biblical Hebrew: Semantic and Morphological Overlap
}

\author{
Joel S. Baden \\ Yale Divinity School
}

\begin{abstract}
The well-established semantic overlap between the niphal and hithpael in Biblical Hebrew is explained by the morphological similarities between the two stems in the imperfect form in the consonantal text. This claim is supported by a statistical analysis indicating that the first root consonant of some verb classes has assimilated rather than undergone metathesis more commonly than has previously been thought.
\end{abstract}

\section{Keywords}

Biblical Hebrew, hithpael, niphal

The standard grammars of Biblical Hebrew have long recognized the semantic overlap between the niphal and the hithpael. ${ }^{1}$ Lambdin considers the hithpael to be primarily reflexive, while the niphal is "medio-passive"; yet the niphal can also have reflexive meaning. ${ }^{2}$ Similarly, Waltke \& O'Connor describe the hithpael as the reflexive-reciprocal counterpart of the piel, and the niphal as the middle and passive counterpart of the qal. They go on to

\footnotetext{
1) There is a respectable amount of scholarship on the historical development of the hithpael in Biblical Hebrew, especially regarding the probability that the relatively standardized Hebrew form is in fact a conflation of a variety of earlier t-stem forms. Cf. U. Ornan, "Two Types of Hitpa 'el", in M. Goshen-Gottstein, S. Morag, and S. Kogut, eds., Studies on Hebrew and Other Semitic Languages (Jerusalem, 1990), pp. 1-3 [Hebrew]; E. A. Speiser, "The Durative Hithpa'el: A tan Form", JAOS 75 (1955), pp. 118-121; B. W. W. Dombrowski, "Some Remarks on the Hebrew Hithpa 'el and Inversative -t- in the Semitic Languages", JNES 21 (1962), pp. 220-223; M. L. Boyle, "Infix-T Forms in Biblical Hebrew" (unpublished dissertation, Boston University, 1969); D. Yellin, "The Hippa'el-Nif'al Conjugation in Hebrew and Aramaic, and the Assimilation of $\Omega$ in the Hitpa'el Conjugation", JPOS 4 (1924), pp. 85-106; M. Arnold, Categorization of the Hitpa'el of Classical Hebrew (Harvard University dissertation, 2005).

2) T. O. Lambdin, Introduction to Biblical Hebrew (Upper Saddle River, NJ, 1971), pp. 175, 249. 
note, however, that the niphal has a reflexive function which corresponds with the primary function of the hithpael, and that the hithpael in fact can at times also have a passive meaning. ${ }^{3}$ Joüon-Muraoka state that the hithpael is the reflexive of the piel, and that the principal meaning of the niphal is that of the reflexive of qal. But in addition, they observe, the niphal frequently takes on a purely passive sense in relationship to the qal, and in fact one also finds it as the passive or reflexive of the hiphil and also of the piel. The hithpael, on the other hand, "can have the diverse meanings of the niphal". ${ }^{4}$ Finally, Gesenius informs us that the hithpael is primarily the reflexive of the piel, and is only very rarely passive. The niphal, on the other hand, is primarily reflexive of qal, but also expresses reciprocal or active meanings. Gesenius claims that the niphal only comes to represent the passive of qal "in consequence of a looseness of thought at an early period of the language".

This brief survey of grammars demonstrates not only the common recognition that the hithpael and the niphal overlap significantly in regard to their semantic fields, but also that the historical origins of this overlap are uncertain, and that the direction of the influence from one stem to the other, if such exists, is unclear. In the following study, I hope to demonstrate that the origin of the semantic overlap between the niphal and hithpael lies in their morphologies, as is born out by statistical analysis, and that the direction of influence can be understood from this perspective.

\section{Passive Hithpael}

To begin, we must establish precisely where the semantic overlap between these two stems occurs, and with what frequency and distribution.

Gesenius, Joüon-Muraoka, and Waltke and O'Connor all suggest that there is a passive function associated with the hithpael. ${ }^{6}$ Yet few examples are שקר החן והבל brought in support of this contention. In Prov 31:30 we read "Grace is deceptive, beauty is illusory; it is for her fear of the Lord that a woman is to be praised" [NJPS]). One could, however, read here "it is for her fear of the Lord that a woman gains praise for herself", or "is praiseworthy", either of which would be a suitable non-

\footnotetext{
3) B. K. Waltke \& M. O'Connor, An Introduction to Biblical Hebrew Syntax (Winona Lake, IN, 1990), pp. 379ff., 429.

4) P. Joüon - T. Muraoka, A Grammar of Biblical Hebrew (Rome, 1996), pp. 150, 159.

5) GKC $\$ 51 \mathrm{c}-\mathrm{f}, 54 \mathrm{~d}-\mathrm{g}$.

6) See above.
} 
passive translation for the hithpael. Another example, Qoh 8:10, is considerably more clear: ובכן ראיתי רשעים קברים ובאו וממקום קדוש יהלכו וישתכח בעיר אשר כן־עשו and being brought to burial, while such as had acted righteously were forgotten in the city").

Outside of these two examples provided by Gesenius, only one of which seems unequivocally passive, I have located only two other unambiguously passive hithpaels.7 One is in 1 Sam 3:14: ולכן נשבעתי לבית עלי אם-יתכפר עון בית־עלי תשתפכנה אבני־קדש :Eli will never be expiated"). The other is in Lam 4:1 בראש כל־חוצות ("The sacred gems are spilled at every street corner"). Though the overall number of occurrences of the hithpael in the Bible varies from study to study, ${ }^{8}$ by any reckoning these three examples of the passive usage are statistically insignificant, and the assessment of Siebesma is to be accepted: "The hitp. may be translated as active, reflexive, or reciprocal, but rarely as passive". ${ }^{2}$

\section{Reflexive Niphal}

The grammars provide various lists of semantically reflexive niphals, the contents of which do not require repeating here; ${ }^{10}$ the existence of the reflexive usage of the niphal is well-attested and universally acknowledged. In this section, then, we will examine only a handful of examples that demonstrate the degree to which the use of the niphal overlaps with that of the hithpael.

\footnotetext{
7) A. F. Bean, in his dissertation on the hithpael ("A Phenomenological Study of the Hithpa'el Verbal System in the Hebrew Old Testament" [unpublished, Southern Baptist Theological Seminary, 1976]), seems to have located 68 examples of hithpaels with passive meanings (p. 150); because he does not cite even a single example by verse, however, his data are difficult to substantiate. Additionally, the concerns of Waltke \& O'Connor are worth noting: they observe that Bean "described his sample according to the structures of the English language" (Syntax, 428). They offer three other proposed passive hithpaels (Isa 30:29; 1 Chr 5:17; 2 Chr 22:6 [Syntax, 432]), but these are, to my mind, relatively ambiguous as to their precise semantics.

8) Waltke \& O'Connor say that there are "over 825" (Syntax, p. 429); Bean counts 946 ("Hithpa'el", p. 44); P. Mazars ("Sens et usage de l'hithpael dans la bible hébraïque", Divinitas 12 [1968], pp. 353-364) finds 780.

9) P. A. Siebesma, The Function of the Niphial in Biblical Hebrew (SSN; Assen/Maastricht, 1991), p. 168. A similar conclusion is drawn by P. Mazars: "Rarement l'hithpael a le sens passif” (“Sens et usage”, p. 353).

10) Joüon-Muraoka, Grammar, pp. 150-151; Waltke \& O’Connor, Syntax, pp. 388-389; GKC $\$ 51 \mathrm{c}$.
} 
In Jer 16:6 we read, ולא-יספדו להם ולא יתגדד ולא יקרח להם ("men shall not lament them, nor gash and tonsure themselves for them"). Though the final verb in the verse, יקרח, is formally a niphal, both context, the lack of a stated object (as is found with the qal form of this verb in Lev 21:5), and the structural parallel with the preceding hithpael, יתגדד, indicate that we should read it, with virtually all modern translations, as reflexive. ${ }^{11}$

A similar situation obtains in the patriarchal promise formulae. As has long been noted, the phrase "all the nations of the earth will bless themselves by you" and its variants appears with both the niphal and the hithpael of the verb ברך. The distribution, moreover, is equal: the niphal appears in Gen $12: 3 ; 18: 8$; 28:14, while the hithpael is used in Gen 22:18; 26:4; Jer 4:2. Because of this distribution, the meaning of the niphal in these formulae has been debated at great length. ${ }^{12}$ Given the rarity of the passive use of the hithpael, as noted above, as well as the fact that the three examples from Genesis are the only attestations of the niphal of ברך in the Bible, it seems more plausible to read these niphal forms as reflexive, rather than assume either that the hithpaels are to be read as passive or that the promise formulae were intentionally written differently in their various occurrences. ${ }^{13}$

In two cases, we find that the niphal and hithpael are confused within the same passage. In Gen 3:8, we read ויתחבא האדם ואשתו מפני יהוה (the man and his wife hid from the Lord God"). In Gen 3:10, when they are discovered, Adam says, ואירא כי־ערום אנכי ואחבא ("I was afraid because I was naked, so I hid"). Despite the semantic similarity between the hithpael and niphal of this verb, it is nevertheless remarkable that here in a single narrative, in precisely the same context, even in the description of the very same act, the two different stems should be used.

Similarly, in Dan 2:1 we read, חלם נבכדנצר חלמות ותתפעם רוחו ("Nebuchadnezzar had a dream; his spirit was agitated"). Two verses later, the king relates his experience to his various counselors: חלום חלמתי ותפעם רוחי ("I had a dream, and my spirit was agitated"). Again, the niphal is used where just two verses previously we had the hithpael. In this case, however, it would

11) The use of the niphal here may be for phonological reasons; W. H. Holladay (Jeremiah 1 [Hermeneia; Philadelphia, 1986], p. 468) suggests intentional wordplay with יקברו earlier in the verse (though he emends the earlier verb from niphal to qal [p. 467]). The reflexive meaning of the niphal passes without comment by Holladay and other commentators.

12) See C. Westermann, Genesis 12-36 (CC; Minneapolis, 1995), pp. 151-152, for a review of the discussion.

13) As Westermann notes (Genesis 12-36, pp. 151-152), the similar use of the hithpael of Ps 72:17 provides additional support to this argument. 
seem that the niphal is the more expected of the two forms, particularly in this context. ${ }^{14}$ This is in fact the only occurrence of the hithpael of this verb in the Bible. Nevertheless, this case, like the last, serves to point out the nearinterchangeability of the two forms, not only across the various books and authors of the Bible, but even within the very same narrative.

As a final piece of evidence for the semantic overlap between the niphal and hithpael, we may examine two cases of confusion in parallel texts. In 2 Sam 10:6 we read, ויראו בני עמון כי נבאשו בדוד ("The Ammonites realized that they had incurred the wrath of David"). The parallel in 1 Chron 19:6, however, reads ויראו בני עמון כי התבאשו עם־דוד. Similarly, Ps 18:26-27: "With" עם־חסיד תתחסד עם־גבר תמים תתמם: עם־נבר תתברר ועם־עקש תתפתל התמוד the loyal, you deal loyally; with the blameless man, blamelessly; with the pure, you act purely, and with the perverse, you are wily"). The structure of these verses, with the hithpael standing at the end of each clause, is clear. The parallel in 2 Sam 22:26-27, however, is problematic: עם־חסיד תתחסד עם־גבור תמים תתמם: עם־גבר תתבר ועם־עקש תתפל. It is obvious that there has been

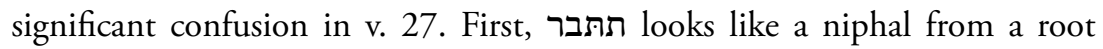
תבר, but this root is otherwise unattested. We may assume that the second resh dropped out through haplography. Second, תתפל in Samuel corresponds to תתפתל in Psalms. The verb in Psalms is clearly the hithpael of a root פתפל, but the form in Samuel, as it stands, cannot be derived from that root. As the verb in Samuel is essentially unreadable, we should propose that the third tav dropped out through haplography. ${ }^{15}$ In either case, textual difficulties notwithstanding, there must have at some point been sufficient belief that these forms were sensible as they stood. In the case of תתפל, this probably simply meant understanding that this new hithpael verbal root had the same meaning as the hithpael of פתל תתבר, Fowever, it was required not only to understand that the new root תבר had the same meaning as ברר מתר , but also that the niphal of this new root was equivalent to the hithpael of the standard root.

Textual problems aside, it is clear enough from these examples that the semantic ranges of the niphal and hithpael overlapped frequently and deeply. It is equally clear that the overlap runs primarily in one direction: the niphal frequently shares the basic reflexive meaning of the hithpael, but the hithpael almost never takes the passive meaning primarily associated with the niphal.

\footnotetext{
14) Cf. Gen. 41:8: ויהי בבקר ותפעם רוחו. The niphal is used also in Ps 77:5.

15) On the text-critical issues in this passage, cf. P. K. McCarter, II Samuel (AB; New York, 1984), pp. 458-459.
} 


\section{Morphological Overlap}

We turn now to the morphology of the hithpael and the niphal where, as with their semantics, there are striking similarities. The rules governing the formation of the hithpael are well established: when the first root consonant is a dental stop (dalet, tet, or tav), then we expect the $t$ from the stem to assimilate to the dental, as in the forms והפהמה (Isa 14:14), והפהוה (Gen 35:2), and והתממהו (Hab 1:5). It is clear that if the $t$ assimilates to the first root consonant, then in a pre-Masoretic unvocalized text the hithpael in the imperfect will be indistinguishable from the niphal. ${ }^{16} \mathrm{It}$ is not surprising that we in fact get forms in which this confusion is evident. Twice in Job $(5: 4 ; 34: 25)$ we find the form ("they will be crushed"). The degeshim in the dalet and kaf suggest that this form was read as a hithpael from דכא in which the $t$ of the hithpael has assimilated to the dalet. Yet semantically this verb is clearly passive. It is simple enough to emend the text by removing the dagesh from the kaf and changing the patah to a qames, thus rendering this a niphal.

More striking is the case of the root טמא. As the following chart indicates, this root breaks down distinctively by both stem and form:

$\begin{array}{ll}\text { Niphal } & \text { Hithpael } \\ \text { Lev 11:43 } & \text { Lev 11:24 } \\ \text { Lev 18:24 } & \text { Lev 11:43 } \\ \text { Num 5:13 } & \text { Lev 18:24 } \\ \text { Num 5:14 } & \text { Lev 18:30 } \\ \text { Num 5:20 } & \text { Lev 21:1 } \\ \text { Num 5:27 } & \text { Lev 21:3 } \\ \text { Num 5:28 } & \text { Lev 21:4 } \\ \text { Num 5:29 } & \text { Lev 21:11 } \\ \text { Jer 2:23 } & \text { Num 6:7 } \\ \text { Ezek 20:30 } & \text { Ezek 14:11 } \\ \text { Ezek 20:31 } & \text { Ezek 20:7 } \\ \text { Ezek 20:43 } & \text { Ezek 20:18 } \\ \text { Ezek 23:7 } & \text { Ezek 37:23 } \\ \text { Ezek 23:13 } & \text { Ezek 44:26 } \\ \text { Ezek 23:30 } & \text { Hos 9:4 } \\ \text { Hos 5:3 } & \\ \text { Hos 6:10 } & \text { total } \\ \text { 18 } & \text { all imperfect } \\ \text { all perfect } & \end{array}$

16) This well-established morphological overlap between the imperfects of the hithpael and 
The distribution among the texts is virtually identical, with examples in Leviticus, Numbers, Ezekiel, and Hosea in both forms, and a single example of the niphal in Jeremiah. In every occurrence of this verb it has the same meaning: "to purify oneself". However, all fifteen examples of the hithpael of טמא are in the imperfect; all eighteen examples of the niphal are in the perfect. ${ }^{17}$ Given the previously noted morphological overlap between the niphal and hithpael in the imperfect of I-dental roots, the assumption must be that there has been confusion of the hithpael and niphal in the imperfect. Because the niphal perfects are unambiguously marked by their initial $n$, and given the complete absence of any hithpael perfects, it seems probable that the hithpael was in fact not a productive stem for this root, and that the imperfects should all be repointed as niphals. This, however, begs the question of how they became pointed as hithpaels in the first place if the hithpael was otherwise unattested. The most likely answer is that later scribes recognized that these verbs were semantically reflexive, which they associated with the hithpael; as they were loath to change the consonantal text, there was little to be done about the niphal perfects, but the imperfects could be and were repointed to make them the expected hithpael form. ${ }^{18}$ The evidence of the distribution of טמא gives us no insight into the origin of the semantic overlap between niphal and hithpael, but rather points out quite clearly the effects of said overlap: that the niphal and hithpael of this one verb could be read and understood as having the exact same meaning suggests that the two were seen as nearly, if not entirely, identical.

In addition to I-dental roots, the form of the hithpael changes if the first root consonant is a dental fricative, i.e., zayin, samech, and tzade, or one of the other sibilants sin or shin. ${ }^{19}$ Here, as is well known, we expect the $t$ to

niphal is paralleled in their imperative and infinitive forms (i.e., those in which the niphal takes a $h i$-prefix); there too the $t$ of the hithpael assimilates to the I-dental root, rendering it consonantally (and nearly phonologically) identical to the niphal. The historical development of the $h i$ - prefix in the niphal and hithpael is evidently parallel as well, in both cases being analogous to the $h$ of the causative stem; cf. W. R. Garr, "The Niphal Derivational Prefix", Orientalia 62 (1993), pp. 142-162.

17) This distribution has been noted by Yellin (apud Bergsträsser, Hebraïsche Grammatik [Hildesheim, 1962] 2:\$16d) and Siebesma (Niph'al, p. 169), who notes a similar phenomenon among four other roots (דכא, גאל, ברר, and כסה). Neither, however, attributes this situation to a definitive historical development, as is proposed below.

18) This development may have been impacted also by the increasing use of the hithpael in later Biblical Hebrew; cf. Bean, "Hithpa'el", pp. $149 f f$.

19) Technically, zayin, samech, and tzade are the de-affricated Hebrew equivalents of the protoSemitic affricates ${ }^{\mathrm{d}} \mathrm{z},{ }^{\mathrm{t}} \mathrm{s}$, and 's'. On the proto-Semitic affricate, see R. Steiner, Affricated sade in 
undergo metathesis, such that we get the following forms: מסתתר (1 Sam 23:19); ישתרגו ויצטירו (Jos 9:4) ואשתמר (Pam 1:14); 18:24).

The question regarding these forms, specifically the I-affricates, is whether they always metathesize in the hithpael. Though previously unnoted in scholarship, there is good evidence that they do not - that, like the I-dentals, they in fact frequently assimilate. Two examples stand out as occasions where a I-affricate has assimilated rather than metathesized. The first is the form in Isa 1:16. Here a reflexive is clearly required: "purify yourselves"-and a hithpael therefore expected. ${ }^{21}$ The dagesh in the kaf supports this reading, but the $t$ must have assimilated to the zayin, where we would, in theory, expect it to metathesize.

יתבררו The second example is in Dan 12:10. Here we have a series of verbs "Many will purify themselves, purge themselves, and [ostensibly] be refined"). ${ }^{22}$ Given the preceding forms, it seems likely that the third verb, ויצרפו, should be read as a hithpael, "they will refine themselves", in which the $t$ has assimilated to the tzade, rather than as a niphal. ${ }^{23}$ If this is the case, then we have examples of both zayin and tzade assimilating rather than metathesizing as expected.

These two examples are hardly probative by themselves, but they may become more significant when viewed as part of a statistical analysis of the hithpael in I-affricate roots in the Hebrew Bible. If we examine the relative frequency of hithpaels in all roots, we find that there are significantly fewer hithpaels not only in I-dental roots, which we would expect given the established morphological overlap with the niphal, but also in I-affricate roots.

the Semitic Languages (AAJRMS 3; New York, 1982); A. Faber, "Akkadian Evidence for ProtoSemitic Affricates", JCS 37 (1985): pp. 101-107. See also the chart of proto-Semitic consonants in J. Huehnergard, "Afro-Asiatic", in the Cambridge Encyclopedia of the World's Ancient Languages (ed. R. D. Woodard; Cambridge, 2004), pp. 138-159 (chart on p. 142).

20) Though many grammars also indicate that in I-zayin roots the zayin and tav metathesize and the tav becomes a dalet, this situation is in fact unattested in Biblical Hebrew. It is represented in Aramaic (cf. הזדמנתון, Dan 2:9 [qere]) and later forms of Hebrew, however.

21) As argued by Gesenius (GKC $\$ 54 \mathrm{~d}$ ).

22) Virtually all modern translations read all three verbs as passive, rather than reflexive; however one interprets the hithpael here, it is probable that all three verbs were intended to be the same both semantically and morphologically.

23) 4QFlor provides the expected form of the hithpael here (יצטרפו) (apud J. J. Collins, Daniel [Hermeneia; Minneapolis, 1993], p. 369). 


\begin{tabular}{|c|c|c|c|c|c|}
\hline IRL & Roots & R \% & T-stems & Т \% & IRL \% \\
\hline א & 66 & 4.3 & 14 & 6.2 & 21 \\
\hline ב & 64 & 4.2 & 10 & 4.4 & 15 \\
\hline$\lambda$ & 52 & 3.4 & 15 & 6.6 & 28 \\
\hline ד & 47 & 3.1 & 6 & 2.6 & 12 \\
\hline ה & 26 & 1.7 & 4 & 1.8 & 15 \\
\hline 1 & 0 & 0.0 & 0 & 0.0 & - \\
\hline$T$ & 46 & 3.0 & 1 & 0.4 & 2 \\
\hline$\pi$ & 125 & 8.2 & 20 & 8.8 & 16 \\
\hline 0 & 30 & 2.0 & 2 & 0.8 & 7 \\
\hline , & 72 & 4.7 & 9 & 4.0 & 13 \\
\hline כ & 61 & 4.0 & 7 & 3.1 & 11 \\
\hline 3 & 39 & 2.5 & 9 & 4.0 & 23 \\
\hline מ & 72 & 4.7 & 11 & 4.8 & 15 \\
\hline J & 135 & 8.8 & 21 & 9.3 & 15 \\
\hline ס & 55 & 3.6 & 4 & 1.8 & 7 \\
\hline ע & 127 & 8.3 & 23 & 10.1 & 18 \\
\hline פ & 81 & 5.3 & 14 & 6.2 & 17 \\
\hline$y$ & 60 & 3.9 & 2 & 0.8 & 3 \\
\hline P & 71 & 4.6 & 9 & 4.0 & 13 \\
\hline ר & 105 & 6.9 & 17 & 7.5 & 16 \\
\hline ש & 46 & 3.0 & 5 & 2.2 & 11 \\
\hline ש & 120 & 7.8 & 20 & 8.8 & 17 \\
\hline$ת$ & 31 & 2.0 & 3 & 1.3 & 10 \\
\hline Mean & 66.6 & 4.4 & 9.9 & 4.3 & 13.3 \\
\hline
\end{tabular}

KEY: $I R L=$ initial root letter

Roots = Raw number of attested verbal roots with given IRL

$\mathrm{R} \%=$ Percentage of total number of verbal roots

T-stems = Raw number of verbal roots with given IRL with attested t-stem form $^{24}$

$\mathrm{T} \%=$ Percentage of total number of verbal roots with attested $\mathrm{t}$-stem form IRL \% = Percentage of verbal roots with given IRL with attested t-stem form

24) For the purposes of this statistical analysis, all t-stem forms (hithpael, hothpael, hithpoel, etc.) have been considered. 
This chart bears explaining. Using aleph, therefore, as an example: there are 66 verbal roots in Biblical Hebrew beginning with aleph. I-aleph roots make up $4.3 \%$ of all verbal roots in Biblical Hebrew. Within those 66 I-aleph roots, fourteen have a t-stem. Those fourteen, in turn, make up $6.2 \%$ of all verbal roots with at least one attested t-stem form in Biblical Hebrew. The final column tells us that $21 \%$ of the I-aleph verbs have at least one attested t-stem form. The row at the bottom of the chart labeled "mean" gives a rough estimate of the averages for each column.

The column labeled "T\%" tells us that the verbal roots which produce the fewest t-stems, in order from fewest to relatively greatest, are I-zayin, I-tet, I-tzade, I-tav, I-samech, I-sin, and I-heh. Three of these are the dental affricates, and two are dental stops. However, the value of the non-affricates in this list is reduced somewhat when we note that the results of this column are not weighted according to the total number of attested verbal roots. In other words, heh may have a small percentage of the total t-stems in Biblical Hebrew, but that is because it has only $1.7 \%$ of the total verbal roots in Biblical Hebrew. The best measure for the prevalence of $\mathrm{t}$-stems within a particular consonant-initial verbal root is the column labeled IRL\%, where we can see what percentage of verbal roots within a particular consonant-initial group have attested t-stems.

When the data in the IRL\% column are considered, we find that among the lowest percentages heh has dropped out, with 15\% (noting the rough mean of $13.3 \%$ ). The affricates, however, remain: zayin with $2 \%$, tzade with $3 \%$, and samech with $7 \%$. Note that the dentals are, as expected, among the lowest in this regard: dalet with $12 \%$, tet with $7 \%$, and tav with $10 \%$. Sin is also relatively low, with $11 \%$.

Remarkably, then, I-affricate roots are the least likely to have hithpael forms, according to the breakdown on the chart-even less likely than dentals. I believe that this pattern can be explained only by asserting that the hithpaels in these roots have assimilated, rather than metathesized, much more often than is usually allowed, and that many, if not most, of these assimilated forms were subsequently reanalyzed, and then used productively, as niphals. ${ }^{25}$

25) Though this study is concerned exclusively with the evidence from Biblical Hebrew, it is worth noting that in Ugaritic there are no attested t-stems for I-dental roots, a phenomenon undoubtedly due not to a real lack of such forms, but the assimilation of the $t$ to the first consonant (as noted already by Boyle, "Infix-T Forms", p. 137). In addition, however, though Ugaritic has numerous attested Gt forms of I- $s$ and I- $\underline{t}$ roots (which is similar to the situation in 
The first step in the reconstruction of the development of the semantic overlap between hithpael and niphal, then, is based on the recognition of the morphological overlap found particularly in I-dental and I-affricate roots. These forms may have provided a pattern from which subsequent developments arose. It is acknowledged that other roots also occasionally assimilate, even those which we expect not even to metathesize. Notable are the verbs נבא both of which have two attestations in which the $t$ has assimilated. ${ }^{26}$ Gesenius notes that we also find assimilation with kaf, shin, and resh. ${ }^{27}$ If we add the examples with zayin and tzade given above, we can point to nine different initial roots which show at least one example of assimilation; this does not include samech, for which we have no clear examples, but which, based on the statistical evidence, must have also assimilated. Thus nearly half of the alphabet shows assimilation to one degree or another. It is likely that assimilation of the $t$ to the initial root consonant was carried out first in the dentals, expanded quickly to the affricates, and, having covered six letters of the alphabet, expanded further from there, such that assimilation became a valid, if infrequent, option for the formation of the hithpael.

\section{Conclusion}

The foregoing analysis provides us with a strong base of evidence from which to consider the development of the semantic overlap between niphal and hithpael. If, in fact, it was more common than is usually thought for the $t$ of the hithpael to assimilate to the first root consonant, and if, as we have seen, it is quite possible for these assimilated forms to be reanalyzed as niphals, then the possibility must be seriously considered that these reflexive niphals began to penetrate the language more regularly. In other words, the reflexive sense began to take on a regularity within the semantic field of the niphal,

\footnotetext{
Hebrew, in which the hithpael of $\boldsymbol{w}$ is found more frequently than average), there is only one $\mathrm{t}$-stem of any other I-affricate $(s-r)$. Thus the conclusions drawn here for the historical development in Hebrew may be transferred, at least in part, to Ugaritic.

26) נשא For see Num 24:7; Dan 11:14. For נבא see Jer 23:13; Ezek 37:10.

27) GKC \$54c. His examples are from Prov 26:26 (תכספה); Num 21:27 (תפונן); Qoh 7:16 (תשומם); Isa 33:10 (ארומם). Yellin ("Hippa'el-Nif'al Conjugation") claims these as examples of his proposed "hippa'el" form; see, however, Waltke \& O'Connor (Syntax, p. 425): "The socalled Hippael forms... may be considered examples of irregular assimilations", as suggested by Gesenius and here.
} 
such that it became possible for the niphal to become a productive reflexive stem in some cases. This would account for the existence of verbs which have both niphal reflexives and hithpael reflexives; either was a valid option. By recognizing the greater degree to which hithpaels assimilated unexpectedly, we can see how the niphal began to be used as a productive reflexive stem. ${ }^{28}$

28) Though it falls outside the limited scope of this study, of related interest along the lines suggested above may be the development of the nithpael stem in Mishnaic Hebrew. This form occurs as the replacement of the perfect of the hithpael, and is used as the reflexive/passive of the piel stem, while the niphal retains its expanded use as the passive/reflexive of the qal. Because the pual ceased to function productively in Mishnaic Hebrew, the hithpael/nithpael took on a far greater role in expressing the passive of the piel than was the case in Biblical Hebrew, perhaps analogously to the rise of the niphal in Biblical Hebrew at the expense of the qal passive. The $n$-preformative was apparently a result of the association of the $h$-preformative with the causative, and, on the pattern of the niphal, the $n$-preformative with the passive/ reflexive. Cf. M. H. Segal, A Grammar of Mishnaic Hebrew (Oxford, 1958), pp. 62-67; E. Y. Kutscher, A History of the Hebrew Language (Jerusalem, 1982), p. 127. 